\title{
Beneficial roles of Song-Gang stone as a feed additive in aquaculture: a review
}

\author{
Gwangyeol Yoo ${ }^{1}$, Zeinab Abediostad ${ }^{2}$, Wonsuk Choi ${ }^{3}$, Jinho Bae ${ }^{3}$, Youn Hee Choi ${ }^{4}$, Seunghyung Lee ${ }^{4, *}$, \\ Sungchul C. Bai ${ }^{2, *}$ \\ ${ }^{1}$ Food \& Biological Resources Examination Division, Korean Intellectual Property Office, Daejeon 35208, Korea \\ ${ }^{2}$ FAO World Fisheries University Pilot Program, Feeds \& Foods Nutrition Research Center, Pukyong National University, Busan 48513, Korea \\ ${ }^{3}$ Feeds \& Foods Nutrition Research Center, Pukyong National University, Busan 48513, Korea \\ ${ }^{4}$ Department of Aquaculture, College of Fisheries Science, Pukyong National University, Busan 48547, Korea
}

\begin{abstract}
Song-Gang ${ }^{\circledast}$ bio-stone (SGS) is a microporous crystalline hydrated aluminosilicate which has found various applications because of their very unique physiochemical characteristics such as ion exchange and absorptive-desorptive properties. Significant progress has been made in recent years on applications of these inorganic adsorbents in different industries including agriculture, aquaculture, water and wastewater treatment. This review article intends to summarize the published reports on the applications of SGS in aquaculture industry. SGS application as a feed additive to enhance fish growth and promote their health and nutritional parameters is the most important discussed areas. According to the technical data that are discussed in this review, SGS should be considered as a material with tremendous potential for application in the aquaculture industry. Considerable amounts of research works are under way to explore other opportunities for application of SGS to benefit aquaculture industry.
\end{abstract}

Keywords: Song-Gang ${ }^{\circledR}$ bio-stone, Antibiotic replacer, Feed additives, Growth, Immune responses

\section{Introduction}

In the last few decades, aquaculture has become the fastest growing food industry in the world. Intensified culture systems cause a variety of health and environmental problems, and animals reared under stress are subject to compromised growth and immune responses (Bondad-Reantaso et al., 2005;
Sahin et al., 2014). Aquaculture feeds are formulated with a vast pool of ingredients which are intended to supply nutritional requirements to perform its normal functions, including maintaining a highly effective natural immune system, growth, and reproduction. Many different feed additives are being used in aquatic feed to ensure the dietary nutrients are ingested, digested, absorbed, and transported to the cells (Savira \& Suharsono,

Received: Jul 20, 2021 Revised: Sep 23, 2021 Accepted: Nov 16, 2021

${ }^{\star}$ Corresponding author: Seunghyung Lee

Department of Aquaculture, College of Fisheries Science, Pukyong National University, Busan 48547, Korea

Tel: +82-51-629-5916, E-mail: shlee@pknu.ac.kr

*Corresponding author: Sungchul C. Bai

FAO World Fisheries University Pilot Program, Feeds \& Foods Nutrition Research Center, Pukyong National University, Busan 48513, Korea

Tel: +82-51-629-6673, E-mail: scbai@pknu.ac.kr

This is an Open Access article distributed under the terms of the Creative Commons Attribution Non-Commercial License (http://creativecommons.org/licenses/by$\mathrm{nc} / 4.0 /$ ) which permits unrestricted non-commercial use, distribution, and reproduction in any medium, provided the original work is properly cited.

Copyright $\odot 2021$ The Korean Society of Fisheries and Aquatic Science 
2013). There are various functional feed additives for these purposes, which can be classified by their chemical composition and origin. Potential feed additives should be selected based on their effect, contribution and commercial availability (Bae et al., 2020). Feed additives are nutritive/non-nutritive compounds that would be applied to the diet of fish and shrimps to influence physical or chemical property of the diet (Bai et al., 2015; NRC, 2011). These feed additives have a very different chemical nature and vary considerably in their use in marketable diet formulations for aquatic species.

Additives are used in fish feed to maintain the dietary characteristics of a diet or feed ingredients prior to feeding (e.g., antioxidant, mold inhibitors), improve ingredient dispersion or feed pelleting (e.g., emulsifiers, stabilizers, binders), encourage feed ingestion and consumer acceptance of the product (e.g., feed stimulants, food colorants), promote growth (e.g., growth promoters, including antibiotics and hormones), and supply essential nutrients in concentrated and/or purified forms (e.g., vitamins, minerals, amino acids, cholesterol, phospholipids) (Ajiboye et al., 2012). Dietary additive studies in juvenile fish (Park et al., 2016; Sharifuzzaman \& Austin, 2010) are normally conducted for 1-8 weeks (Bondad-Reantaso et al., 2005) whereas in larger fish, longer durations of experimentation may be required to understand the effects of additives in fish (Shin et al., 2014). Feed additives for cultured aquatic animals have impacts on growth performances, immune response, resistance to diseases and intestinal microbial communities (Kesarcodi-Watson et al., 2008; Merrifield et al., 2010; Ringø et al., 2012; Zokaeifar et al., 2012). In order to improve growth and immunity, several of these additives have commercial potential for the promotion of growth and immune responses in the aquaculture industry (Ai et al., 2007; Choi et al., 2004; Güroy et al., 2014; Lee et al., 2015; NRC, 2011; Shahkar et al., 2015). However, in individual fish species, each dietary additive can produce different levels of response and contribute differently to feed cost. Consequently, in the present study, I aimed to review the dietary effects of a natural mineral material, Song-Gang ${ }^{\circledR}$ bio-stone (SGS, Davistone, Busan, Korea) as a growth promoter in fish.

\section{Nature of Song-Gang ${ }^{\circledR}$ bio-stone}

Naturally occurring minerals are homogeneous material formed from one or a compound of elements through geological processes. Natural minerals are generally soil-based particles altered by the weathering action of bio-stone containing silicon dioxide $\left(\mathrm{SiO}_{2}\right)$ at $40 \%-80 \%$ and aluminum oxide $\left(\mathrm{Al}_{2} \mathrm{O}_{3}\right)$ at
$10 \%-30 \%$ as the main components (Yoon \& Park, 2009). They can be used with other mineral oxides as effective and useful feed additives such as iron oxide $\left(\mathrm{Fe}_{2} \mathrm{O}_{3}\right)$, calcium oxide $(\mathrm{CaO})$, magnesium oxide $(\mathrm{MgO})$, potassium oxide $\left(\mathrm{K}_{2} \mathrm{O}\right)$, sodium oxide $\left(\mathrm{Na}_{2} \mathrm{O}\right)$ and titanium oxide $\left(\mathrm{TiO}_{2}\right)$ in the diets for animal (Yoon \& Park, 2009). Some studies have suggested a possible improvement of growth, immune response and water quality by supplementing natural minerals in fish diets (Table 1). Naturally occurring minerals may also fight gastrointestinal diseases by mixing with noxious compounds, altering nutrient usage in the intestine, and positively impacting animal health ( $\mathrm{Lv}$ et al., 2015; Zhang et al., 2013). Natural mineral feed additives have some potential as replacements for antibiotics (Safaeikatouli et al., 2011; Yenice et al., 2015). In livestock, minerals delay the transit time of feed in the intestine. This mechanism of action improves acid capacity and feed use rate (Kermanshahi et al., 2011), increasing the absorption of moisture and the ability to trade in ions, thereby reducing the incidence of intestinal stools and harmful gasses which improve the environment (Joo et al., 2007). Feed quality improvements include inhibition of the survival of fungi and harmful bacteria and adsorbing toxins in the feed, thus improving the health of cultured livestock (El-Melegy et al., 2015). SGS is a naturally sourced and purified mineral material from the Republic of Korea comprising predominantly of iron oxide $\left(\mathrm{Fe}_{2} \mathrm{O}_{3}\right)$, silicon dioxide $\left(\mathrm{SiO}_{2}\right)$, aluminum oxide $\left(\mathrm{Al}_{2} \mathrm{O}_{3}\right)$, potassium oxide $\left(\mathrm{K}_{2} \mathrm{O}\right)$, sodium oxide $\left(\mathrm{Na}_{2} \mathrm{O}\right)$, titanium dioxide $\left(\mathrm{TiO}_{2}\right)$, etc. (Lee et al., 2015; Won et al., 2017). It is considered to be one of the important naturally sourced mineral materials that improves the health status of fish (Choi et al., 2004; Lee et al., 2015; Won et al., 2017). For the confirmation of ingredients of mineral mixture, the X-ray fluorescence spectrometer (XRF) (ARL PERFORM'X, Thermo Fisher Scientific, Waltham, MA, USA) was used to determine the mineral composition of the mixture $\left(\mathrm{SiO}_{2}, \mathrm{Al}_{2} \mathrm{O}_{3}, \mathrm{Fe}_{2} \mathrm{O}_{3}, \mathrm{CaO}, \mathrm{MgO}, \mathrm{K}_{2} \mathrm{O}\right.$, $\mathrm{Na}_{2} \mathrm{O}, \mathrm{TiO}_{2}$ ) according to the method (KSE3076) of Korean standards for mine (Korea Standard Association, 2002). In brief, a certain amount of each of the pulverized sample and a binder (polyvinyl chloride or PVC dissolved in toluene) was added carefully, mixed and pressed in a hydraulic chamber to form a pellet. The sample chamber (analyzer) of the spectrometers was then fitted with the pellet and the X-rays emitted at a voltage (up to $30 \mathrm{kV}$ ), and with a current (up to $1 \mathrm{~mA}$ ). The software attached to the spectrometer was then calibrated and operated for around 30 to 60 seconds, and the results were then displayed automatically (Table 2). These natural minerals are like zeolites, 
Table 1. Effects of natural minerals and their effects in various fish species

\begin{tabular}{|c|c|c|c|c|c|}
\hline Natural minerals & Zeolite & & Montmorillonite & Bentonite & Mordenite \\
\hline Fish species & Tilapia (Tilapia zillii) & $\begin{array}{l}\text { Rainbow trout (Oncorhyn- } \\
\text { chus mykiss) }\end{array}$ & Rainbow trout (O. mykiss) & Rainbow trout (O. mykiss) & Rainbow trout (O. mykiss) \\
\hline $\begin{array}{l}\text { Addition concentration } \\
\text { range (\%) }\end{array}$ & $0,1,2$ & 0,1 & $0,1,2,4$ & $0,2.5,5$ & $0,2.5,5$ \\
\hline $\begin{array}{l}\text { Optimum concentration } \\
\text { (\%) }\end{array}$ & 1 & 1 & 1 or 2 & 5 & 2.5 \\
\hline Fish size (g) & $1.08 \pm 0.01$ & 87.9 & $0.5 \pm 0.03$ & $104.2 \pm 0.7$ & $104.2 \pm 0.7$ \\
\hline Duration (days) & 45 & 150 & 90 & 90 & 90 \\
\hline Effects & $\begin{array}{l}\uparrow \text { PER, } \\
\downarrow \text { Total ammonia }\end{array}$ & $\uparrow W G, F E$ & $\begin{array}{l}\uparrow \text { WG, SGR, FE, non-spe- } \\
\text { cific humoral immune } \\
\text { responses }\end{array}$ & $\uparrow W G, F E, S G R$ & $\uparrow \mathrm{WG}, \mathrm{FE}, \mathrm{SGR}$ \\
\hline Water temperature $\left({ }^{\circ} \mathrm{C}\right)$ & $24.6 \pm 0.77$ & $11.4-14.0$ & $10.6 \pm 2$ & $14.0-16.0$ & $14.0-16.0$ \\
\hline $\mathrm{pH}$ & $8.33 \pm 0.18$ & $7.29-7.52$ & $7.0 \pm 0.2$ & NT & \\
\hline $\mathrm{DO}(\mathrm{mg} / \mathrm{L})$ & $6.27 \pm 0.66$ & $10.4-11.2$ & $7.0 \pm 0.1$ & $6.0-9.0$ & $6.0-9.0$ \\
\hline Source & Yıldırım et al. (2009) & Obradović et al. (2006) & Karimi et al. (2020) & Eya et al. (2008) & Eya et al. (2008) \\
\hline
\end{tabular}

$\uparrow$ symbol, increase; $\downarrow$ symbol: decrease .

PER, protein efficiency ratio (\%); WG, weight gain (\%); FE, feed efficiency (\%); SGR, specific growth rate (\%/day); NT, not tested.

Table 2. Chemical composition of the natural mineral materials of Song-Gang ${ }^{\circledR}$ bio-stone (\% DM, dry matter basis)

\begin{tabular}{ll}
\hline Minerals & Song-Gang ${ }^{\oplus}$ bio-stone \\
\hline $\mathrm{SiO}_{2}$ & 73.4 \\
$\mathrm{Al}_{2} \mathrm{O}_{3}$ & 15.5 \\
$\mathrm{Fe}_{2} \mathrm{O}_{3}$ & 0.87 \\
$\mathrm{CaO}$ & 0.91 \\
$\mathrm{MgO}$ & 0.09 \\
$\mathrm{~K} \mathrm{O}$ & 4.31 \\
$\mathrm{Na}_{2} \mathrm{O}$ & 4.19 \\
$\mathrm{TiO}_{2}$ & 0.03 \\
\hline
\end{tabular}

Values are means of duplicate samples.

which are commonly used in aquaculture as an additive. Zeolite mainly has a $\mathrm{SiO}_{2}$ component and other components of the primary mineral source, some of which are micronutrients (Roland \& Kleinschmit, 1996).

\section{Effects of Song-Gang ${ }^{\circledR}$ bio-stone in fresh water and marine fish}

The previous studies of SGS in fish are summarized in Table 3. The effectiveness of SGS has been evaluated as a dietary supplement for a variety of cultured aquatic organisms. Evaluations of this sort generally consider time-course, dosage, and the responses of fishes or crustaceans to experimental exposure as seen in their growth performances, immune status and disease resistance. The SGS is a rich mineral source, which reduces the entry of pathogenic bacteria through the adsorption of harmful gas. It is free of toxins and heavy metals, and is recognized as having some potential as a healthy, low-cost dietary additive for commercial aquaculture (Bae et al., 2020). This discussion consists of a summary of the reactions of freshwater and marine fishes to experimental SGS supplementation. Feeding trials have been reported in fresh water species such as rainbow trout (Oncorhynchus mykiss), and juvenile Amur catfish (Silurus asotus), the catadromous Japanese eel (Anguilla japonica), and marine species including olive flounder (Paralichthys olivaceus). Rainbow trout, (O. mykiss) exhibited enhanced weight gain and improved immune status in response to SGS supplemented diets as compared with controls (Won et al., 2017). These increases were comparable to beneficial responses observed in response to other dietary additives, leading the authors to conclude that this mineral supplement has potential applicability as a replacement for antibiotic treatments currently in use. A similar trial of SGS dietary supplementation in juvenile Amur catfish (S. asotus) demonstrated significant growth and immune status enhancements as compared with controls, also suggesting that this mineral feed additive offers an economically appealing option for improved performance in this species (Amoah et al., 2017). Bae et al. (2008) investigated the effects of dietary supplementation of SGS either alone or in combination with a "feed stimulant" in juvenile Japanese eels (Anguilla japonica). These au- 
Table 3. Summary of the previous studies on Song-Gang ${ }^{\circledR}$ bio-stone (SGS) in fish diet

\begin{tabular}{|c|c|c|c|c|c|c|}
\hline & $\begin{array}{l}\text { Japanese eel (An- } \\
\text { guillajaponica) }\end{array}$ & $\begin{array}{l}\text { Rainbow trout (Onco- } \\
\text { rhynchus mykiss) }\end{array}$ & $\begin{array}{l}\text { Rainbow trout ( } O \text {. } \\
\text { mykiss) }\end{array}$ & $\begin{array}{l}\text { Amur catfish (Silurus } \\
\text { asotus) }\end{array}$ & $\begin{array}{l}\text { Olive flounder (Para- } \\
\text { lichthys olivaceus) }\end{array}$ & $\begin{array}{l}\text { Olive flounder ( } P . \\
\text { olivaceus) }\end{array}$ \\
\hline $\begin{array}{l}\text { Addition concentration } \\
\text { range (\%) }\end{array}$ & $0,0.7$ & $0,0.4$ & $0,0.4$ & $0,0.4$ & $0,0.4$ & $0,0.4$ \\
\hline $\begin{array}{l}\text { Optimum concentra- } \\
\text { tion (\%) }\end{array}$ & 0.7 & 0.4 & 0.4 & 0.4 & 0.4 & 0.4 \\
\hline Fish size (g) & $15 \pm 0.1$ & $2.7 \pm 0.02$ & $261.5 \pm 3.5$ & $4.95 \pm 0.05$ & $10.98 \pm 0.13$ & $5.26 \pm 0.17$ \\
\hline Duration (weeks) & 8 & 8 & 22 & 8 & 8 & 8 \\
\hline Effects & $\begin{array}{l}\uparrow \text { WG, FE, SGR, PER, } \\
\text { survival }\end{array}$ & $\begin{array}{l}\uparrow \mathrm{FE}, \mathrm{PER}, \uparrow \mathrm{FE}, \mathrm{PER}, \\
\text { SOD, MPO, LYZ } \\
\text { activities, survival }\end{array}$ & $\begin{array}{l}\uparrow \text { WG, FE, SGR, PER, } \\
\text { SOD, MPO, LYZ, } \\
\text { NBT activities }\end{array}$ & $\begin{array}{l}\uparrow \text { WG, FE, SGR, PER, } \\
\text { SOD }\end{array}$ & $\begin{array}{l}\uparrow \mathrm{SOD}, \mathrm{MPO}, \mathrm{LYZ}, \\
\text { survival }\end{array}$ & $\begin{array}{l}\uparrow \text { WG, FE, SGR, } \\
\text { MPO, NBT activity, } \\
\text { survival }\end{array}$ \\
\hline $\begin{array}{l}\text { Water temperature } \\
\left({ }^{\circ} \mathrm{C}\right)\end{array}$ & $25 \pm 1$ & $15 \pm 0.5$ & $15 \pm 4.5$ & $25.0 \pm 0.1$ & & $18 \pm 1.0$ \\
\hline $\mathrm{pH}$ & NT & $7.5 \pm 0.3$ & $7.6 \pm 0.3$ & & & \\
\hline $\mathrm{DO}(\mathrm{mg} / \mathrm{L})$ & NT & Near saturation & $6 \pm 0.6$ & & & \\
\hline Source & Bae et al. (2008) & Won et al. (2017) & Won et al. (2017) & Amoah et al. (2017) & Oncul et al. (2017) & Bae et al. (2020) \\
\hline
\end{tabular}

$\uparrow$ symbol: Increase.

WG, weight gain (\%); FE, feed efficiency (\%); SGR, specific growth rate (\%/day); PER, protein efficiency ratio (\%); SOD, superoxide dismutase (\% inhibition); MPO, myeloperoxidase (absorbance); LYZ, lysozyme $\left(\mathrm{U} \mathrm{mL}^{-1}\right)$; NBT, nitroblue tetrazolium (absorbance); NT, not tested.

thors reported that the combination treatment produced some beneficial responses including improved growth performances and increased survival rate in response to a challenge with an exogenous pathogen. A study by Oncul et al. (2017) with feeding trials of fermented tuna by-product containing SGS in olive flounder (P. olivaceus) diet, revealed positive effects on non-specific immune responnses such as lysozyme, superoxide dismutase (SOD) and myeloperoxidase (MPO) activities; and enhanced resistance to bacterial infection. Also, Bae et al. (2020) conducted beneficial effects on growth and feed utilization performance, MPO and nitro-blue-tetrazolium (NBT) activity and survival of olive flounder (P. olivaceus) fed low-fishmeal (FM) diets.

These studies revealed a trend favoring enhancements of growth performances and disease resistance in response to SGS treatment, without definitively establishing a mechanism of action. These responses are comparable to enhancements seen in response to oxytetracycline (OTC), and for this reasons SGS is viewed as a possible replacement to antibiotic therapy. Beneficial antibiotic effects have tentatively been attributed to increased nutrient absorption in response to a thinning in the gastrointestinal lining, the decrease in harmful bacteria that otherwise would secrete harmful metabolic by-products, and/ or a reduction in nutrient competitiveness between host animals and bacteria (Marshall \& Levy, 2011). However, evidence of hazards associated with routine antibiotic use are leading to its elimination in large-scale aquaculture activities (Hernandez-Serrano, 2005; Marshall \& Levy, 2011).

\section{Conclusion}

In conclusion, previous studies demonstrating that SGS may be a safe, effective, and affordable supplement for improving growth efficiency and resistance to pathogens in fresh water and marine fish and they suggest its further evaluation as a dietary replacement for the antibiotic, OTC. In order for these findings to be widely used in other fish species, further studies on the mass production, safety, and toxicity of SGS are needed.

\section{Competing interests}

No potential conflict of interest relevant to this article was reported.

\section{Funding sources}

This work was supported by a Research Grant of Pukyong National University(2021).

\section{Acknowledgements}

We thank all the members of the Feeds \& Foods Nutrition Research Center (FFNRC), Pukyoung National University, Busan 


\section{Availability of data and materials}

Upon reasonable request, the datasets of this study can be available from the corresponding author.

\section{Ethics approval and consent to participate}

Institutional Review Board Statement: Fish handling and euthanizing were approved by the Animal Use and Care Committee of Pukyong National University (protocol number 554).

\section{ORCID}

Gwangyeol Yoo

Zeinab Abediostad

Wonsuk Choi

Jinho Bae

Youn Hee Choi

Seunghyung Lee

Sungchul C. Bai https://orcid.org/0000-0002-8615-0135 https://orcid.org/0000-0003-0810-1108 https://orcid.org/0000-0003-0990-0163 https://orcid.org/0000-0001-9006-6844 https://orcid.org/0000-0002-1407-9296 https://orcid.org/0000-0003-0914-9613 https://orcid.org/0000-0001-7984-2267

\section{References}

Ai Q, Mai K, Zhang L, Tan B, Zhang W, Xu W, et al. Effects of dietary $\beta-1,3$ glucan on innate immune response of large yellow croaker, Pseudosciaena crocea. Fish Shellfish Immunol. 2007;22:394-402.

Ajiboye OO, Yakubu AF, Simpa JO, Balogun SA. Effect of garlic-supplemented diets on growth response, survival, nutrient utilization and body composition of monosex tilapia zillii. World J Fish Mar Sci. 2016;8:115-22.

Amoah YT, Moniruzzaman M, Lee S, Bae J, Won S, Seong M, et al. Evaluation of different dietary additives based on growth performance, innate immunity and disease resistance in juvenile Amur catfish, Silurus asotus. Int Aquat Res. 2017;9:351-60.

Bae J, Hamidoghli A, Won S, Choi W, Lim SG, Kim KW, et al. Evaluation of seven different functional feed additives in a low fish meal diet for olive flounder, Paralichthys olivaceus. Aquaculture. 2020;525:735333.

Bae JY, Han KM, Lee JH, Kim SE, Lee JY, Bai SCC. Effects of dietary quartz porphyry and feed stimulants, BAISM supplementation on growth performance and disease resistance of juvenile eel Anguilla japonica. J Aquac. 2008;21:26-33.

Bai SC, Katya K, Yun H. 7 - Additives in aquafeed: an overview. In: Allen Davis D, editor. Feed and feeding practices in aquaculture. Lisle Township, IL: Woodhead; 2015. p. 171202.

Bondad-Reantaso MG, Subasinghe RP, Arthur JR, Ogawa K, Chinabut S, Adlard R, et al. Disease and health management in Asian aquaculture. Vet Parasitol. 2005;132:249-72.

Choi SM, Ko SH, Park GJ, Lim SR, Yu KY, Lee JH, et al. Utilization of Song-Gang stone as the dietary additive in juvenile olive flounder, Paralichthys olivaceus. J Aquac. 2004;17:3945.

El-Melegy KM, Shehata SA, Abdel-Salam AF, Ragheb EM. Influence of bentonite and ascorbic acid on minimizing the toxicity of aflatoxin $B_{1}$ in chicks diet. Egypt J Poult Sci. 2015;35:527-42.

Eya JC, Parsons A, Haile I, Jagidi P. Effects of dietary zeolites (bentonite and mordenite) on the performance juvenile rainbow trout Onchorhynchus myskis. Aust J Basic Appl Sci. 2008;2:961-7.

Güroy B, Mantoğlu S, Kayalı S, Şahin İ. Effect of dietary Yucca schidigera extract on growth, total ammonia-nitrogen excretion and haematological parameters of juvenile striped catfish Pangasianodon hypophthalmus. Aquac Res. 2014;45:647-54.

Hernandez-Serrano P. Responsible use of antimicrobials in aquaculture. FAO Fisheries Technical Paper, No. 469. Rome: FAO; 2005.

Joo EJ, Jung SJ, Son JH, Cho JK, Youn BS, Nam KT, et al. Effect of dietary supplement of fermented clay mineral on the growth performance and immune stimulation in broiler chickens. Korean J Poult Sci. 2007;34:231-6.

Karimi M, Mousavi SM, Zolgharnain H, Zakeri M. Dietary montmorillonite as growth promoter and immunomodulator in rainbow trout (Oncorhynchus mykiss). Chemosphere. 2020;252:126459.

Kermanshahi H, Jani EHA, Hashemipour H, Pilevar M. Efficacy of natural zeolite and pigments on yolk color and performance of laying hens. Afr J Biotechnol. 2011;10:3237-42.

Kesarcodi-Watson A, Kaspar H, Lategan MJ, Gibson L. Probiotics in aquaculture: the need, principles and mechanisms of action and screening processes. Aquaculture. 2008;274:1 14.

Korea Standard Association. 2002. Methods for X-ray fluorescence spectrometric analysis of silica stone and silica sand. Seoul: KSA; 2002. Standard No.: KSE 3076.

Lee YK, Katya K, Yun HH, Yoon MY, Park JK, Sung JS, et al. Evaluation of dietary yellow loess as an antibiotic replacer on growth, immune responses, serological characteristics and disease resistance in rainbow trout, Oncorhynchus my- 
kiss. Aquac Nutr. 2015;22:1018-25.

Lv Y, Tang C, Wang X, Zhao Q, Zhang J. Effects of dietary supplementation with palygorskite on nutrient utilization in weaned piglets. Livest Sci. 2015;174:82-6.

Marshall BM, Levy SB. Food animals and antimicrobials: impacts on human health. Clin Microbiol Rev. 2011;24:71833.

Merrifield DL, Dimitroglou A, Foey A, Davies SJ, Baker RTM, Bøgwald J, et al. The current status and future focus of probiotic and prebiotic applications for salmonids. Aquaculture. 2010;302:1-18.

National Research Council. Nutrient requirements of fish. Washington, DC: National Academy Press; 2011.

Obradović S, Adamović M, Vukašinović M, Jovanović R, Levic $\mathrm{J}$. The application effects of natural zeolite in feed and water on production results of Oncorhynchus mykiss (Walbaum). Roum Biotechnol Lett. 2006;225:153.

Oncul FO, Aya FA, Seong M, Lee JH, Bai SC. Effect of fermented tuna by-product containing diets with and without Song-Gang stone ${ }^{\circledR}$ on growth, immune response and disease resistance in juvenile olive flounder Paralichthys olivaceus. Paper presented at: Conference of the Korean Federation of Fisheries Science and Technology Societies; 2017; Tongyeong, Korea.

Park Y, Moniruzzaman M, Lee S, Hong J, Won S, Lee JM, et al. Comparison of the effects of dietary single and multi-probiotics on growth, non-specific immune responses and disease resistance in starry flounder, Platichthys stellatus. Fish Shellfish Immunol. 2016;59:351-7.

Ringø E, Olsen RE, Vecino JLG, Wadsworth S, Song SK. Use of immunostimulants and nucleotides in aquaculture: a review. J Mar Sci Res Dev. 2012;2:104.

Roland E, Kleinschmit P. Zeolites, Ullmann's encyclopedia of industrial chemistry. Weinheim: Wiley-VCH Verlag GmbH \& Co.; 1996.

Safaeikatouli M, Jafariahangari Y, Baharlouei A. An evaluation on the effects of dietary kaolin and zeolite on broilers blood parameters, T4, TSH and growth hormones. Pak J Nutr. 2011;10:233-7.

Savira F, Suharsono Y. Self-regulated learning (SRL) dengan prokrastnasi akademik pada siswa akselerasi. J Ilmiah Psikologi Terapan. 2013;1:66-75.

Sahin K, Yazlak H, Orhan C, Tuzcu M, Akdemir F, Sahin N. The effect of lycopene on antioxidant status in rainbow trout (Oncorhynchus mykiss) reared under high stocking density.
Aquaculture. 2014;418-419:132-8.

Shahkar E, Park G, Lee DM, Kwak S, Bai SC. Effects of dietary Macsumsuk $^{\circledR}$ supplementation on growth performance, haematological parameters, disease resistance and body composition of juvenile Nile tilapia, Oreochromis niloticus L. J Appl Anim Res. 2015;43:125-30.

Sharifuzzaman SM, Austin B. Kocuria SM1 controls vibriosis in rainbow trout (Oncorhynchus mykiss, Walbaum). J Appl Microbiol. 2010;108:2162-70.

Shin CH, Cha JH, Rahimnejad S, Jeong JB, Yoo BW, Lee BK, et al. Effects of dietary supplementation of Barodon, an anionic alkali mineral complex, on growth performance, feed utilization, innate immunity, goblet cell and digestibility in olive flounder (Paralichthys olivaceus). Asian-Australas J Anim Sci. 2014;27:383-90.

Won S, Moniruzzaman M, Lee S, Hong J, Park JK, Kim S, et al. Evaluation of dietary natural mineral materials as an antibiotic replacer on growth performance, non-specific immune responses and disease resistance in rainbow trout, Oncorhynchus mykiss. Aquac Res. 2017;48:4735-47.

Yenice E, Mizrak C, Ceylan N, Yildiz T, Gültekin M, Atik Z. Effects of dietary sodium bentonite and mannan oligosaccharide supplementation on performance, egg quality, blood and digestion characteristics of laying hens fed aflatoxin contaminated diet. Kafkas Univ Vet Fak Derg. 2015;21:211-8.

Yıldırım Ö, Türker A, Şenel B. Effects of natural zeolite (clinoptilolite) levels in fish diet on water quality, growth performance and nutrient utilization of tilapia (Tilapia zillii) fry. Fresenius Environ Bull. 2009;18:1567-71.

Yoon MY, Park JK. Effect of $\mathrm{SiO}_{2}$-ionized loess on the treatment of tinea pedis. Biotechnol Bioprocess Eng. 2009;14:400-5.

Zhang J, Lv Y, Tang C, Wang X. Effects of dietary supplementation with palygorskite on intestinal integrity in weaned piglets. Appl Clay Sci. 2013;86:185-9.

Zokaeifar H, Luis Balcázar J, Kamarudin MS, Sijam K, Arshad A, Saad CR. Selection and identification of non-pathogenic bacteria isolated from fermented pickles with antagonistic properties against two shrimp pathogens. J Antibiot. 2012;65:289-94. 